\title{
Institutional Pressures, Sustainable Development Goals and COVID-19: How Are Organisations Engaging?
}

\author{
Bárbara Galleli *(D), Elder Semprebon, Joyce Aparecida Ramos dos Santos (D, Noah Emanuel Brito Teles (D), \\ Mateus Santos de Freitas-Martins and Raquel Teodoro da Silva Onevetch
}

\begin{abstract}
Business Department, Federal University of Parana, Curitiba 80210-170, Brazil; elder.semprebon@ufpr.br (E.S.); joysantosap@gmail.com (J.A.R.d.S.); noahbteles@gmail.com (N.E.B.T.); mateussfmartins@gmail.com (M.S.d.F.-M.); raquelonevetch@hotmail.com (R.T.d.S.O.)

* Correspondence: barbara.galleli@ufpr.br
\end{abstract}

check for

updates

Citation: Galleli, B.; Semprebon, E.; Santos, J.A.R.d.; Teles, N.E.B.; Freitas-Martins, M.S.d.; Onevetch, R.T.d.S. Institutional Pressures, Sustainable Development Goals and COVID-19: How Are Organisations Engaging?. Sustainability 2021, 13, 12330. https://doi.org/10.3390/ su132112330

Academic Editor: Gisela Cebrián

Received: 2 October 2021

Accepted: 5 November 2021

Published: 8 November 2021

Publisher's Note: MDPI stays neutral with regard to jurisdictional claims in published maps and institutional affiliations.

Copyright: (c) 2021 by the authors. Licensee MDPI, Basel, Switzerland. This article is an open access article distributed under the terms and conditions of the Creative Commons Attribution (CC BY) license (https:// creativecommons.org/licenses/by/ $4.0 /)$.

\begin{abstract}
This article aimed at answering the following research question: How do institutional pressures influence the engagement of organisations with the Sustainable Development Goals (SDGs) in the context of the COVID-19 pandemic? To address it, we applied a survey with Brazilian organisations in late 2020. From group analysis and the comparison of means (test-t), we conclude that, in the pandemic scenario, organisations from various sectors and industries are affected mainly by coercive pressures but also by normative and, to a lesser extent, mimetic pressures. Furthermore, this study has shown that while opportunities are arising from normative and mimetic institutional pressures, it is in the coercive pressures that the guidance lies for the re-establishment of economic, social, and environmental development and prosperity in a post-pandemic scenario. Thus, despite some optimistic results, achieving the purpose outlined by the 2030 Agenda seems to be distant or at least needs an even more substantial effort if its responsibility rests solely with legislative and governmental forces.
\end{abstract}

Keywords: sustainable development; 2030 Agenda; coronavirus; survey; group analysis; global compact

\section{Introduction}

In early 2020, the world faced the emergence and spread of an unknown virus named the Coronavirus (COVID-19) [1]. The high potential lethality of COVID-19 led different nations to adopt various preventive measures [2]. Researchers agreed that, when combined, the various restrictive policies, such as social isolation and quarantine, followed mainly from the World Health Organisation's [3] guidelines, acted as the most effective mechanism for containing the virus $[2,4]$. However, in practice, adopting such measures has brought distinct consequences globally, such as the temporary shutdown of schools, universities, and public and private companies [5].

Given the negative impacts caused by the spread of the virus, ranging from high mortality rates to increased unemployment, trade shutdowns, and, consequently, a decline in the growth forecasts of countries [5], private organisations have proven to be key allies in addressing such externalities. By the time this research was carried out, one could perceive a collective engagement of companies in different parts of the world, taking actions to address the consequences of COVID-19 [6].

As a worldwide public health issue, the pandemic of COVID-19 still impacts environmental sustainability, social responsibility, and people's quality of life [2]. It is assumed that the consequences of the pandemic will extend for a long period [7] and may even negatively influence the achievement of global goals and targets, such as the Sustainable Development Goals (SDGs) of the UN [8].

Presented by the 2030 Agenda, the SDGs are divided into 17 main targets and, from a broad perspective, are directed at poverty eradication, the sustainable management of 
natural resources, and the pursuit of prosperity in harmony with nature [9]. Discussions on the negative influence of COVID-19 on the SDGs are widespread in the academic and institutional environment. Authors state that the pandemic is affecting institutions worldwide and that this poses a severe threat to the achievement of the SDGs, especially for eight of them: SDG 1; SDG 2; SDG 3; SDG 4; SDG 5; SDG 8; SDG 10; and SDG 16 [8]. Similarly, other studies concluded that all the SDGs are adversely impacted by COVID-19, with significant consequences for SDG 3 (Good Health and Well-being) [7].

Institutional perspectives, mainly from neo-institutionalism [10], have brought a wide range of insights for understanding sustainability in the organisational context and its deployments. Several scholars have noted the significance of institutional pressures in organisations to perceive sustainable practices as legitimate and adopt them [11]. The institutional theory allows understanding that the organisational movement towards SD responds to institutional pressures of a coercive, normative, or mimetic nature imposed by the environment [12-14].

In this paper, we will argue that institutional pressures motivate organisations to make their actions more sustainable. In the context of the COVID-19 pandemic, these pressures may be even more intense and come from several sources simultaneously. As a result, the pandemic aggravates or exposes economic, social, and environmental problems worldwide. Although previous research emphasises that the pandemic may challenge the global commitment to the 2030 Agenda [15], the growth of expectations about how organisations can contribute to minimizing the damage arising from it represents a topic that needs further investigation.

Considering the recent and potential negative impacts caused by COVID-19 for the achievement of the SDGs, we argue that the lenses of institutional theory can be used as a basis for investigating the engagement of organisations in taking actions for addressing the 2030 Agenda. In this sense, we present the following research question: How do institutional pressures influence the engagement of organisations with the Sustainable Development Goals (SDGs) in the context of the COVID-19 pandemic? To address it, we applied a survey with Brazilian organisations, public, private, and non-governmental, in late 2020.

This study provides theoretical and practical contributions as follows: first, the possibility to investigate how the influence of institutional pressures on organisational actions related to sustainable development, in such an unprecedented, contemporaneous context, can expand the applicability of this theory in the field of knowledge, as suggested by previous studies $[13,16]$. Second, this study's results reinforced the need to expand and deepen knowledge about the engagement of public organisations with sustainable development in general and the SDGs in particular. Third, from a practical point of view, clarifications regarding the companies' engagement concerning the SDGs may elucidate what has been done by the organisational environment so far and provide insights on actions that may be replicated or corrected in the future.

Besides this introductory section, the study is structured as follows: initially, we expose the institutional theory, which will provide the theoretical background to the research. Then, in sequence, we develop and present the hypothesis and the conceptual model of the research. Next, we expose the method procedures applied and present and discuss the results. Finally, we present the conclusions, limitations, and suggestions for future studies.

\section{Institutional Pressures}

The institutional theory seeks to understand the influence that the institutional environment exerts on organisational behaviour. As stated by Scott [17] (p. 48), "institutions are made up of regulatory, normative and cultural-cognitive elements that, together with the associated activities and resources, provide stability and meaning to social life". From this theoretical perspective, organisational decisions or actions are not driven solely by efficiency but by external environmental factors and the need for legitimacy [18]. In other 
words, institutional studies aim to identify pressures that delimit and shape organisational action, coercing companies to resemble each other through isomorphism [19].

Based on this understanding, DiMaggio and Powell [20] discuss the existence of three types of institutional pressures, responsible for triggering organisational isomorphism, namely coercive, normative, and mimetic pressures. The coercive pressures present themselves to the firms formally or informally by means of the organisations considered at a superior level. They are built on exchange relationships and can be a direct response to governmental actions [20]. Such pressure is based on the regulatory pillar, related to processes involving rules, compliance procedures among organisations, and, if necessary, the imposition of sanctions, influencing future behaviours through specialized actors [17].

Mimetic pressures, in turn, occur in response to symbolic uncertainties that influence organisations to rely on legitimised entities as a model for their actions [20]. These pressures reflect the social-cognitive pillar through definitions that arise from the interaction between institutions and are maintained or modified as they are employed to give meaning to the continuity of events [17].

Normative pressures are those composed of social pressures on the organisation and its individuals in order to conform to certain norms associated with professionalisation [20]. Such pressures infer in the normative pillar a relationship that relates both with valuescovering what is intended or desirable - as with norms that refer to the right way of doing things [17].

Thus, assuming that the pressures can delimit and shape organisational action [13], the study on their influence becomes relevant to understanding the practices and motivations in the affected organisations. Parallel to this, it is noteworthy that institutional pressures can provoke variations in the organisations' decision-making processes [21]. As Scott [17] emphasized, the degree of institutional pressure imposed upon firms depends on the actors' interpretation, manipulation, revision, and elaboration. This argument allows one to assume that distinct actors within different industries may present various extents of discretion and motives for dealing with institutional requirements.

The increasing regulatory and social pressure for organisations to take responsibility and seek solutions to the social and environmental problems of today [22] makes it possible to assume that there is a movement for the institutionalisation of sustainable development in the behaviour and policies of organisations. Thus, contributing to a more sustainable future of the planet becomes part of the social demands and expectations in several countries $[22,23]$. The next topic discusses the influence of institutional pressures on organisations and their contributions to the SDGs in the pandemic context and presents the research hypotheses.

\section{Hypothesis Development: Institutional Pressures on Organisations and Actions Addressed to the $\mathrm{SDG}_{\mathrm{S}}$}

Published in the 2030 Agenda, the SDGs embrace a set of 169 targets to be achieved by 2030. Perceived as an opportunity for organisations to develop and provide economic, social, and environmental gains [23], the SDGs represent a pathway for engagement and reporting practices on sustainable development topics. Figure 1 shows a graphical representation of the SDGs.

There are indications that the consequences of COVID-19 on the economy will be very sharp and continuous, and this represents a serious threat to current expectations regarding the achievement of the UN SDGs [8]. According to the Sustainable Development Goals Report 2020—-from the UN Department of Economic and Social Affairs [24], COVID-19 threatens to reverse the progress of several SDGs [25].

Examples of this regression can be assigned to SDG 3, as many non-COVID-19 health services are neglected. SDG 10 is also threatened by the imminent global economic recession, which pushes millions of people back into poverty. This, consequently, impacts SDG 2, as extreme poverty increases hunger around the world. SDG 4 is also likely to be affected in this context, as millions of children worldwide were deprived of formal education during the outbreak of COVID-19 [8,25]. Furthermore, the UN [24] report warns 
that if there is no cooperation between nations, political tensions caused by COVID-19 and the hardening of national borders may undermine SDG 16, the promotion of peace and security, as well as SDG 17, the strengthening of international partnerships [25].
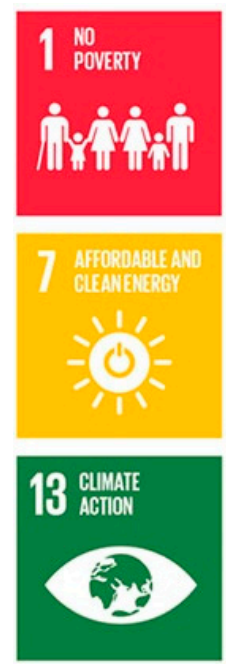
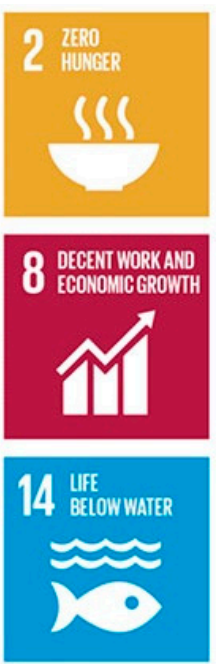
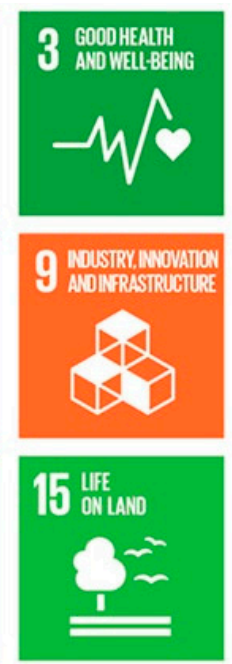
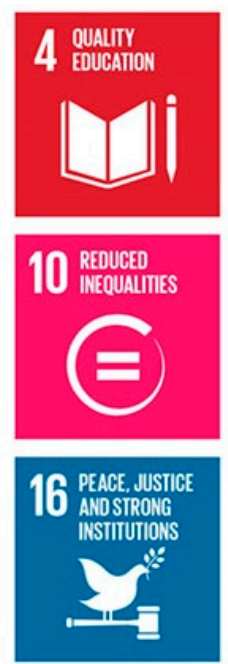
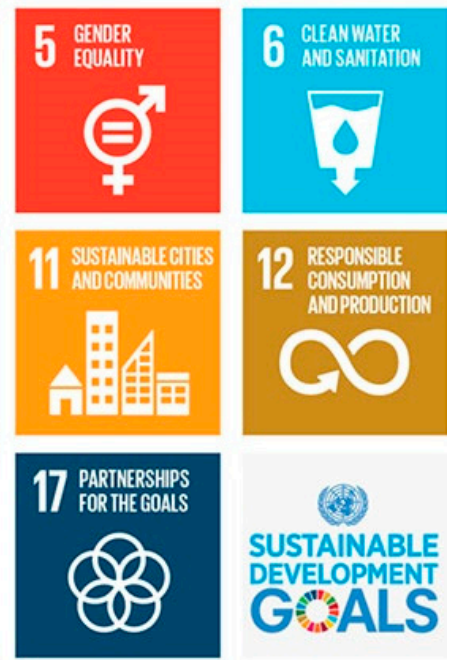

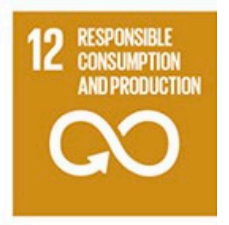

(6)

SUSTAINABLE DEVELOPMENT GALS

Figure 1. Sustainable development goals. Source: [9].

Although progress has been made on SDG 5, the reduction in gender inequality, women's well-being has been threatened with an increasing incidence of domestic violence [25]. Data also show that the environmental sustainability targets covered by SDGs 7, 8 , and 9 and 11 to 15 are not being met [24]. Lozano and Barreiro-Gen [26] confirmed how the COVID-19 pandemic has affected corporations' sustainability efforts and reinforced such an assumption.

Despite this, the UN remains optimistic and presents a blueprint to "defeat the virus and build a better world" by calling for international solidarity and encouraging leading economies to develop coordinated, decisive, inclusive, and innovative policy actions. Achieving the transformative vision of the SDGs requires reorienting the national priorities of virtually all nations towards long-term action [25]. In fact, studies before the pandemic had already stated that for the SDGs to become a reality, the involvement of a wide range of sectors of society would be necessary, as they offer unique opportunities to permanently transform the nature of global development and make sustainable development a defining feature of economic activity [27].

So, if, on the one hand, experts view with pessimism the fulfilment of the 2030 Agenda in the post-pandemic context, on the other hand, one should stress that the global crises triggered by COVID-19 have highlighted that the pursuit and implementation of the SDGs are more important now than they have ever been. We agree with such a vision, especially in view of the fact that these goals can represent the way to restore the world's quality of life [8].

According to the World Business Council for Sustainable Development [28], the COVID-19 pandemic has the potential to be a catalyst for positive change. In their view, precisely because it is so disruptive a shock to the global economic and political systems, there is also the possibility that COVID-19 will help accelerate the emergence of a turning point for the establishment of more responsible businesses favouring sustainable development.

Considering that sustainable development-oriented changes may be associated with a new cultural context, we assume the institutional pressures [20] to be motivating factors for organisations interested in social adequacy and sustainability scenarios to achieve legitimacy with customers, public institutions, and other stakeholders [12,29].

In the pandemic context of COVID-19, organisations are exposed to diverse expectations. This situation means that the pressures, whether coercive, normative, or mimetic, 
may be intensified in this scenario because the demands are for organisations to start "doing more" to contribute in some way to the new circumstances experienced [30]. Lozano and Barreiro-Gen [26], in their survey with more than 100 companies, compared the drivers for sustainability prior to and during COVID-19 and concluded that, prior to the outbreak, the drivers were skewed towards internal factors, with external stimuli accounting for a little bit more than a fifth of the cases. However, during COVID-19, the external stimuli increased to almost a third. Given such arguments, we present Hypothesis 1 (H1):

Hypothesis 1 (H1). Institutional pressures influence organisations to address the Sustainable Development Goals.

Normative pressures may be related to professionalisation, influencing institutional change mechanisms [20]. Formal education establishes professional norms and rules that can influence more conscious organisational behaviours [13]. The commitment of managers can exert significant influence so that organisations change their behaviour and show more empathy for issues related to sustainable development [31], which can influence and modify the behaviour of organisations towards reducing inequalities (SDG 10) or being more responsible and inclusive (SDG 16).

Normative pressures also refer to the managers' performance in trade and industry associations or partnerships between a specific group of organisations [19]. Generally, these groups have their own rules and norms that determine how "things should work" [29]. Regarding the influence of normative pressures in the context of the pandemic, the Global Compact may be exerting normative pressures on organisations. One UN action that illustrates this pressure was its appeal to raise US $\$ 2$ billion to help contain COVID-19 [8]. Therefore, the involvement of some organisations with the SDGs during the pandemic may be a type of normative pressure coming from partnerships and alliances within a specific group. In this sense, we posit H1a:

H1a. Normative institutional pressures influence organisations in addressing the Sustainable Development Goals.

Regarding the coercive pressures associated with adopting sustainable practices in organisations, the literature shows that they arise from regulations and legislation required by the state [12,32]. Furthermore, the studies demonstrate that when compared to normative and mimetic pressures, coercive pressures have a greater influence on directing more sustainable behaviours, thus generating more positive results for society and the environment [33].

In the pandemic context, the coercive pressures coming from the government require organisations to direct actions to combat the damage caused by COVID-19 [30]. Thus, companies can seek inspiration in the SDGs to help them address problems intensified by the pandemic, such as specific actions to eradicate poverty and hunger [8]. Pressures of this nature also occur due to social impositions, such as from non-governmental organisations (NGOs), activists, and consumer claims for organisations to change their practices [34]. Studies show that organisations have changed their product portfolios and production processes to meet the demands of consumers and NGOs [35].

Concerning SDG 12-Ensure sustainable consumption and production patterns-for example, the pandemic of COVID-19 has aroused a new consumption model. From the demands of social isolation, people are consuming more and even hoarding food and other supplies [36], which in the long run may increase the negative impacts on the environment. Given this fact, it is expected that there will be pressure from policy makers to ensure that at this time and after the pandemic a transition to a more sustainable consumption model may occur [36]. Therefore, we have H1b:

H1b. Coercive institutional pressures influence organisations in addressing the Sustainable Development Goals. 
Mimetic pressures are associated with uncertainty, which may influence organisations to imitate others perceived as legitimate in the institutional field [19]. Changing one's behaviour by adopting more sustainable practices is often a situation that embraces uncertainty [37] due to the lack of information about the outcomes and costs that such changes may entail [33]. Thus, the involvement of organisations with the SDGs may be related to mimetic pressures, i.e., many of them may only be reproducing sustainable development practices, such as actions to combat climate change (SDG 13), based on the behaviour of other organisations seen as legitimate in the field.

Daddi et al. [13] identified that Italian industries, in the search for market leadership, presented mimetic behaviours seeking inspiration in the sustainable strategies and actions of other industries considered leaders in their sphere of operation. Therefore, during the pandemic, a scenario full of uncertainties, it is reasonable to consider that organisations may be imitating the actions and processes implemented by others seen as leaders [30] and having a purpose to participate in the fight against COVID-19. Given the arguments presented, we have the last hypothesis (H1c):

H1c. Mimetic institutional pressures influence organisations in addressing the Sustainable Development Goals.

Figure 2 illustrates the model to be empirically tested.

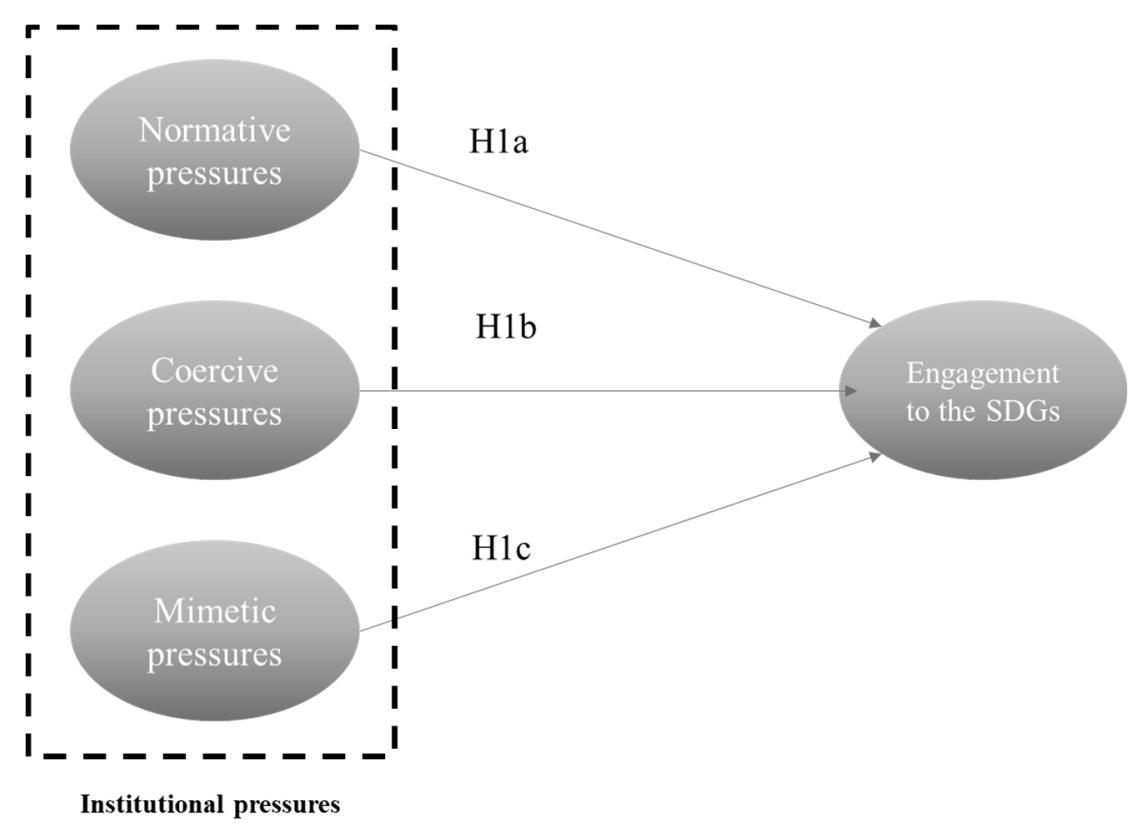

Figure 2. Conceptual research model.

In the next section, we present the methodological procedures carried out in this study.

\section{Method}

The perspective of this research is quantitative; hence, a survey was conducted to achieve the purpose of this study. The survey was developed in the period lasting from October to December 2020 through an online questionnaire applied through the Software Qualtrics, considering one questionnaire per organisation.

The application context was public, private, and non-profit organisations associated with Global Compact Brazil Network, the Brazilian Association of Sustainability Professionals (ABRAPS, acronym in Portuguese), and the Brazilian Commission for Integrated Reporting (CBARI, acronym in Portuguese).

The choice of such organisations was due to their formal interest in the theme as they are part of a professional network. All three of the institutions mentioned above supported the invitation to participate in the research using their mailing and media 
channels. In addition, the organisations were invited via email to participate in the survey by accessing the questionnaire link. The research was applied to the sustainability or correlated area due to their strategic knowledge related to their organisations.

Sampling was made by convenience and was non-probabilistic. A total of 2209 institutions were invited to participate in the survey. It is impossible to specify the overlapping contacts that probably happened, as the same organisations may be active in the three professional networks mentioned. Eventually, we obtained 72 valid questionnaires.

The questionnaire (see Appendix A) was subdivided into four sections, namely: (i) the institution's commitment to the SDGs and their prioritisation in the pandemic context (2 items) [9,38]; (ii) the actions taken by institutions towards combating COVID-19 and the effects of the pandemic on addressing the SDGs (3 items) [38]; (iii) the influence of institutional pressures on the organisation's compliance with the SDGs, in the context of the pandemic ( 3 items) [39-43]. The scale used by the collection instrument involving these three sections was Likert 5 points, with parameters from "strongly disagree" to "strongly agree". The last section was (iv) the organisation profile ( 7 items), according to the Brazilian government classification [44].

The data were analysed using descriptive statistics and group comparison techniques with the IBM SPPS v.21 software.

\section{Results}

The results section is presented as follows: first, we present some descriptive data about the sample profile; second, we present the group analyses from the perceived pressure intensity (high or low) and their development concerning SDG involvement.

Amongst the 72 organisations of the research sample, $47(65.3 \%)$ are private, $15(20.8 \%)$ belong to the third sector, and $10(13.9 \%)$ are public. As to their size, $30(41.7 \%)$ have more than 500 employees, and $22(30.6 \%)$ employ up to 19 people. Most of them $(75 \%)$ are organisations with national coverage. The branches we found most were "other service activities" ( $n=15 ; 20.8 \%)$, education $(n=11 ; 15.3 \%)$, and transformation industries $(n=9$; $12.5 \%)$. Most of the responding organisations are from the states of São Paulo ( $\mathrm{n}=29$; $40.3 \%)$, Paraná ( $\mathrm{n}=14 ; 19.4 \%)$, and Rio de Janeiro $(\mathrm{n}=12 ; 16.7 \%)$.

Regarding the current involvement of organisations with the SDGs, 28 (38.9\%) show already advanced involvement, while $28(38.9 \%)$ show merely initial involvement, and 16 $(22.2 \%)$ are not involved at all.

\section{Groups' Analysis}

To determine two groups in relation to the intensity of pressures suffered by organisations (low-intensity vs. high-intensity), we first created new variables extracted from the general average of the items of each pressure and then classified the two groups according to the median: normative ( 9 items; Alpha $=0.804$; Median $=4.277$ ), coercive ( 9 items; Alpha = 0.916; Median = 4.055), and mimetic (5 items; Alpha = 0.782; Median = 4.000).

Table 1 demonstrates the descriptive profile of each group according to the types of pressure. All the organisations in the sample are in the state of São Paulo and signed the UN Global Compact.

Analysing group description, we noticed that the differences in the groups appear mainly in the industry and the level of commitment to the SDGs. Organisations of health and welfare services (normative pressure), education (coercive pressure), and manufacturing (mimetic pressure) are those that perceived more intensity of institutional pressure, respectively. However, in the case of mimetic pressure, there is still a difference in the profile in relation to the number of employees, as companies that suffer low pressure have less than 19 employees and those that suffer high pressure (mimetic or other types of pressure) have more than 500 employees. 
Table 1. Group description.

\begin{tabular}{|c|c|c|}
\hline & Group-Low-Intensity Pressure & Group-High-Intensity Pressure \\
\hline $\begin{array}{l}\text { Normative } \\
\text { pressure }\end{array}$ & $\begin{array}{l}\text { Private industry, more than } 500 \text { employees, national } \\
\text { operations, service activity industry, and with initial } \\
\text { engagement with the SDGs. }\end{array}$ & $\begin{array}{l}\text { Private industry, more than } 500 \text { employees, national } \\
\text { operations, health, and welfare service industries, and } \\
\text { with advanced engagement with the SDGs. }\end{array}$ \\
\hline $\begin{array}{l}\text { Coercive } \\
\text { pressure }\end{array}$ & $\begin{array}{l}\text { Private industry, more than } 500 \text { employees, national } \\
\text { operations, service activities industries, and with } \\
\text { initial engagement with the SDGs. }\end{array}$ & $\begin{array}{l}\text { Private industry, more than } 500 \text { employees, national } \\
\text { operations, education industry, and with advanced } \\
\text { engagement with the SDGs. }\end{array}$ \\
\hline $\begin{array}{l}\text { Mimetic } \\
\text { pressure }\end{array}$ & $\begin{array}{c}\text { Private industry, up to } 19 \text { employees, national } \\
\text { operations, service activity industry, and with initial } \\
\text { engagement with the SDGs. }\end{array}$ & $\begin{array}{l}\text { Private industry, more than } 500 \text { employees, national } \\
\text { operations, manufacturing industry, and with advanced } \\
\text { engagement with the SDGs. }\end{array}$ \\
\hline
\end{tabular}

From the groups' configuration, it is possible to address the research question, "How do institutional pressures influence organisations' commitment to the Sustainable Development Goals (SDGs) in the context of the COVID-19 pandemic?" Table 2 presents the comparison of means (test-t) in relation to the commitment to each SDG according to the level and type of pressure suffered.

The results achieved for the $t$-test are under the parameters indicated by Pett [45] for the use of parametric tests: (1) independence of observations; (2) observations for the dependent variable were drawn randomly from a normally distributed population (see K-S normality test in Table 2); (3) the dependent variable is measured on at least one interval-level scale; (4) a minimum sample size of approximately 30 subjects per group is recommended; (5) data are extracted from populations with equal variances (see Levene's test in Table 2).

According to the results in Table 2, we can notice that the group that suffers more normative pressure engages more strongly in actions linked to SDG 6-Clean water and sanitation (Sig = 0.01), SDG 14-Life below water (Sig = 0.06), and SDG 15-Life on land $(\mathrm{Sig}=0.00)$. The normative pressures that the organisations significantly perceived were associated to the demands and the example perceived by top management, top-down initiatives, and the formal education of the organisation's members.

Regarding coercive pressures, we observed that when they are of high intensity, they increase the commitment of the organisations to almost all of the Sustainable Development Goals: SDG 2 (Sig = 0.03), SDG 4 ( $\mathrm{Sig}=0.01)$, SDG $5(\mathrm{Sig}=0.03)$, SDG $6(\mathrm{Sig}=0.01)$, SDG $7(\mathrm{Sig}=0.00)$, SDG 9 (Sig = 0.05), SDG 10 (Sig = 0.06), SDG 11 ( $\mathrm{Sig}=0.07)$, SDG 13 (Sig $=0.03)$, SDG $14(\mathrm{Sig}=0.00)$, SDG 15 (Sig = 0.04), SDG $16(\mathrm{Sig}=0.05)$, and SDG 17 (Sig = 0.04 ). In this sense, the presence of coercive pressures exerted mainly by governmental regulations, threats of government legislation in the future, and the actions of activist groups and consumers upon the organisations prompted their commitment to as many as 13 out of the 17 SDGs.

When it comes to mimetic pressures, the group that suffers more pressure is more committed to SDG 2-Zero hunger (Sig = 0.05); SDG 7-Affordable and clean energy (Sig = 0.08); SDG 13-Climate action (Sig = 0.02); SDG 14-Life below water (Sig = 0.04); and SDG 15 - Life and land $(\mathrm{Sig}=0.02)$. The influence of mimetic pressures was detected mainly due to the perception of competition in the sector, the growth of interest, the contribution of investors in SDGs, and issues related to the uncertainty of the results of actions aimed at the SDGs.

The commitment to SDGs 1, 3, 8, and 12 did not change in the presence of any sort of pressure. Thus, the organisations studied did not perceive the influence of coercive, normative, and mimetic pressures that impacted the commitment to actions associated with No poverty (SDG 1), Good health and well-being (SDG 3), Decent work and economic growth (SDG 8), and Responsible consumption and production (SDG 12).

Table 3 presents the correlation analysis amongst institutional pressures and SDGs. 
Table 2. Group description.

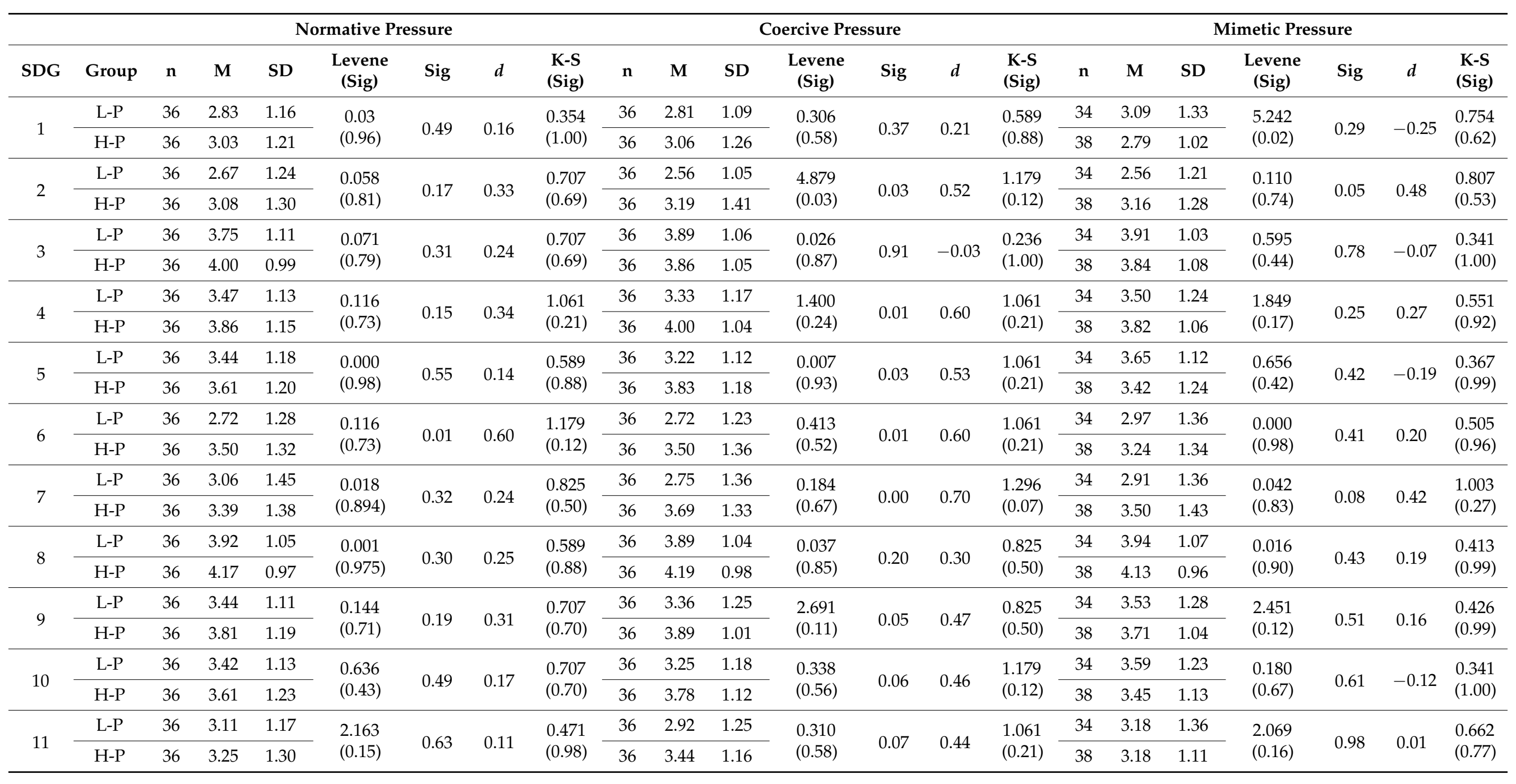


Table 2. Cont.

\begin{tabular}{|c|c|c|c|c|c|c|c|c|c|c|c|c|c|c|c|c|c|c|c|c|c|c|}
\hline \multirow[b]{2}{*}{ SDG } & \multirow[b]{2}{*}{ Group } & \multicolumn{7}{|c|}{ Normative Pressure } & \multicolumn{7}{|c|}{ Coercive Pressure } & \multicolumn{7}{|c|}{ Mimetic Pressure } \\
\hline & & $\mathbf{n}$ & $\mathbf{M}$ & SD & $\begin{array}{c}\text { Levene } \\
\text { (Sig) }\end{array}$ & Sig & $d$ & $\begin{array}{l}\text { K-S } \\
\text { (Sig) }\end{array}$ & $\mathbf{n}$ & $\mathbf{M}$ & SD & $\begin{array}{l}\text { Levene } \\
\text { (Sig) }\end{array}$ & Sig & $d$ & $\begin{array}{l}\text { K-S } \\
\text { (Sig) }\end{array}$ & $\mathbf{n}$ & $\mathbf{M}$ & SD & $\begin{array}{l}\text { Levene } \\
\text { (Sig) }\end{array}$ & Sig & $d$ & $\begin{array}{l}\text { K-S } \\
\text { (Sig) }\end{array}$ \\
\hline \multirow{2}{*}{12} & L-P & 36 & 3.47 & 1.21 & \multirow{2}{*}{$\begin{array}{l}0.482 \\
(0.49)\end{array}$} & \multirow{2}{*}{0.32} & \multirow{2}{*}{0.24} & \multirow{2}{*}{$\begin{array}{l}0.354 \\
(1.00)\end{array}$} & 36 & 3.39 & 1.20 & \multirow{2}{*}{$\begin{array}{l}0.996 \\
(0.32)\end{array}$} & \multirow{2}{*}{0.11} & \multirow{2}{*}{0.38} & \multirow{2}{*}{$\begin{array}{l}0.589 \\
(0.88)\end{array}$} & 34 & 3.50 & 1.26 & \multirow{2}{*}{$\begin{array}{l}1.874 \\
(0.17)\end{array}$} & \multirow{2}{*}{0.45} & \multirow{2}{*}{0.18} & \multirow{2}{*}{$\begin{array}{l}0.452 \\
(0.98)\end{array}$} \\
\hline & $\mathrm{H}-\mathrm{P}$ & 36 & 3.75 & 1.13 & & & & & 36 & 3.83 & 1.11 & & & & & 38 & 3.71 & 1.09 & & & & \\
\hline \multirow{2}{*}{13} & L-P & 36 & 3.11 & 1.39 & \multirow{2}{*}{$\begin{array}{l}0.261 \\
(0.61)\end{array}$} & \multirow{2}{*}{0.19} & \multirow{2}{*}{0.31} & \multirow{2}{*}{$\begin{array}{l}0.707 \\
(0.70)\end{array}$} & 36 & 2.97 & 1.28 & \multirow{2}{*}{$\begin{array}{l}0.002 \\
(0.96)\end{array}$} & \multirow{2}{*}{0.03} & \multirow{2}{*}{0.53} & \multirow{2}{*}{$\begin{array}{l}1.179 \\
(0.12)\end{array}$} & 34 & 2.94 & 1.43 & \multirow{2}{*}{$\begin{array}{l}2.634 \\
(0.11)\end{array}$} & \multirow{2}{*}{0.02} & \multirow{2}{*}{0.55} & \multirow{2}{*}{$\begin{array}{l}1.102 \\
(0.18)\end{array}$} \\
\hline & H-P & 36 & 3.53 & 1.28 & & & & & 36 & 3.67 & 1.33 & & & & & 38 & 3.66 & 1.17 & & & & \\
\hline 14 & $\mathrm{H}-\mathrm{P}$ & 36 & 2.83 & 1.28 & $(0.51)$ & 0.06 & 0.46 & $(0.12)$ & 36 & 2.97 & 1.38 & $(0.01)$ & 0.00 & 0.72 & $(0.07)$ & 38 & 2.84 & 1.24 & $(0.90)$ & 0.04 & 0.50 & $(0.34)$ \\
\hline 15 & L-P & 36 & 2.56 & 1.27 & 0.051 & & & 1.296 & 36 & 2.67 & 1.07 & 8.806 & & & 1.532 & 34 & 2.62 & 1.33 & 0.062 & & & 1.108 \\
\hline 15 & H-P & 36 & 3.42 & 1.23 & $(0.82)$ & 0.00 & 0.69 & $(0.07)$ & 36 & 3.31 & 1.47 & $(0.00)$ & 0.04 & 0.50 & $(0.02)$ & 38 & 3.32 & 1.23 & $(0.80)$ & 0.02 & 0.55 & $(0.17)$ \\
\hline 16 & L-P & 36 & 3.36 & 1.29 & 0.003 & 02 & & 0.471 & 36 & 3.22 & 1.22 & 0.005 & 05 & & 0.943 & 34 & 3.29 & 1.24 & 0.033 & & & 0.918 \\
\hline 10 & H-P & 36 & 3.67 & 1.29 & $(0.95)$ & 0.32 & 0.24 & $(0.98)$ & 36 & 3.81 & 1.31 & $(0.94)$ & 0.05 & 0.46 & $(0.34)$ & 38 & 3.71 & 1.31 & $(0.86)$ & 0.17 & 0.33 & $(0.37)$ \\
\hline & L-P & 36 & 3.31 & 1.21 & 0.603 & & & 0.825 & 36 & 3.22 & 1.35 & 2.186 & & & 1.061 & 34 & 3.32 & 1.36 & 1.326 & & & 0.590 \\
\hline
\end{tabular}

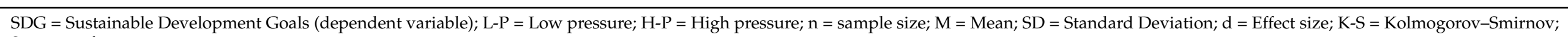
Sig = significance. 
Table 3. Correlation.

\begin{tabular}{|c|c|c|c|c|c|c|c|c|c|c|c|c|c|c|c|c|c|c|c|c|}
\hline & NP & $\mathrm{CP}$ & MP & SDG1 & SDG2 & SDG3 & SDG4 & SDG5 & SDG6 & SDG7 & SDG8 & SDG9 & SDG10 & SDG11 & SDG12 & SDG13 & SDG14 & SDG15 & SDG16 & SDG17 \\
\hline NP & 1 & & & & & & & & & & & & & & & & & & & \\
\hline $\mathrm{CP}$ & $0.528^{* *}$ & 1 & & & & & & & & & & & & & & & & & & \\
\hline $\mathrm{MP}$ & $0.374^{* *}$ & $0.470 * *$ & 1 & & & & & & & & & & & & & & & & & \\
\hline SDG1 & 0.071 & 0.107 & -0.117 & 1 & & & & & & & & & & & & & & & & \\
\hline SDG2 & 0.148 & $0.307^{* *}$ & 0.214 & $0.462 * *$ & 1 & & & & & & & & & & & & & & & \\
\hline SDG3 & 0.178 & 0.099 & -0.099 & $0.415^{* *}$ & $0.272 *$ & 1 & & & & & & & & & & & & & & \\
\hline SDG4 & 0.190 & $0.341 * *$ & 0.175 & $0.284^{*}$ & $0.345^{* *}$ & $0.374^{* *}$ & 1 & & & & & & & & & & & & & \\
\hline SDG5 & 0.195 & $0.320 * *$ & -0.109 & $0.460 *$ & 0.184 & $0.383 * *$ & $0.523 * *$ & 1 & & & & & & & & & & & & \\
\hline SDG6 & 0.229 & $0.367^{* *}$ & 0.122 & 0.156 & $0.360 * *$ & 0.110 & 0.169 & $0.236^{*}$ & 1 & & & & & & & & & & & \\
\hline SDG7 & 0.130 & $0.318^{* *}$ & 0.193 & 0.187 & $0.296^{*}$ & -0.038 & 0.072 & 0.097 & $0.562 * *$ & 1 & & & & & & & & & & \\
\hline SDG8 & $0.306^{* *}$ & $0.262 *$ & 0.088 & $0.262 *$ & $0.233 *$ & $0.403 * *$ & $0.314^{* *}$ & $0.438^{* *}$ & 0.182 & 0.239 * & 1 & & & & & & & & & \\
\hline SDG9 & 0.161 & 0.201 & -0.016 & 0.218 & $0.292 *$ & $0.240^{*}$ & 0.169 & 0.218 & $0.334^{* *}$ & $0.387^{* *}$ & $0.422 * *$ & 1 & & & & & & & & \\
\hline SDG10 & 0.230 & $0.296^{*}$ & -0.055 & $0.525^{* *}$ & $0.344^{* *}$ & $0.442 * *$ & $0.295^{*}$ & $0.510^{* *}$ & $0.319 * *$ & 0.150 & 0.420 ** & $0.403^{* *}$ & 1 & & & & & & & \\
\hline SDG11 & 0.045 & $0.242 *$ & -0.061 & $0.506^{* *}$ & $0.311^{* *}$ & 0.193 & 0.123 & 0.214 & $0.294^{*}$ & $0.439 * *$ & 0.187 & $0.546^{* *}$ & $0.482 * *$ & 1 & & & & & & \\
\hline SDG12 & 0.130 & 0.160 & -0.080 & 0.215 & $0.344^{* *}$ & 0.213 & 0.059 & 0.120 & $0.483 * *$ & $0.453^{* *}$ & 0.252 * & $0.557^{* *}$ & 0.363 ** & $0.570^{* *}$ & 1 & & & & & \\
\hline SDG13 & 0.163 & 0.319 ** & 0.122 & $0.246^{*}$ & $0.353^{* *}$ & 0.129 & 0.143 & 0.140 & $0.463 * *$ & $0.659^{* *}$ & 0.218 & $0.542 * *$ & $0.332 * *$ & 0.710 ** & $0.754^{* *}$ & 1 & & & & \\
\hline SDG14 & 0.154 & $0.354^{* *}$ & 0.231 & $0.305^{* *}$ & $0.559 * *$ & 0.216 & $0.407^{* *}$ & $0.266^{*}$ & $0.584^{* *}$ & $0.441^{* *}$ & 0.149 & $0.323^{* *}$ & $0.361^{* *}$ & $0.405^{* *}$ & $0.393^{* *}$ & $0.483^{* *}$ & 1 & & & \\
\hline SDG15 & $0.243^{*}$ & 0.211 & 0.184 & $0.399 * *$ & $0.376^{* *}$ & 0.142 & 0.062 & 0.158 & $0.366^{* *}$ & $0.493^{* *}$ & 0.180 & $0.422^{* *}$ & $0.251^{*}$ & 0.543 ** & $0.481^{* *}$ & $0.625^{* *}$ & $0.573^{* *}$ & 1 & & \\
\hline SDG16 & 0.170 & $0.267^{*}$ & 0.130 & 0.218 & 0.228 & $0.299 *$ & $0.440^{* *}$ & $0.327^{* *}$ & 0.113 & 0.099 & 0.231 & 0.197 & $0.409 * *$ & 0.163 & 0.162 & 0.197 & $0.399 * *$ & 0.179 & 1 & \\
\hline SDG17 & $0.261 *$ & $0.315^{* *}$ & 0.111 & $0.389 * *$ & $0.386^{* *}$ & $0.513^{* *}$ & $0.428^{* *}$ & $0.371^{* *}$ & $0.292 *$ & 0.168 & $0.298^{*}$ & $0.470^{* *}$ & $0.567^{* *}$ & $0.514^{* *}$ & $0.431^{* *}$ & $0.443^{* *}$ & 0.380 ** & $0.298^{*}$ & 0.423 ** & 1 \\
\hline
\end{tabular}

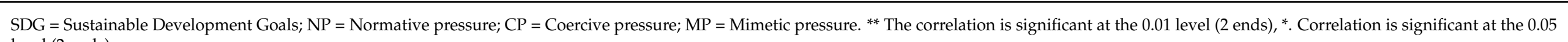
level (2 ends). 
Convergent validity is shown when each measurement item correlates strongly with its assumed theoretical construct, while discriminant validity is shown when each measurement item correlates weakly with all the other constructs except for the one to which it is theoretically associated [46]. The Pearson correlation value (r) can be interpreted using Cohen's criteria of 0,1 for a small correlation; 0,3 for a moderate correlation; and 0, 5 for a large correlation [47]. Table 3 shows that the correlation values between the types of pressure and the SDGs are below or close to 0,3 , which indicates the discriminant validity between the constructs.

\section{Analysis and Discussion}

\subsection{Normative, Coercive, and Mimetic Pressures}

As presented in the previous section, normative pressures were primarily found in the health and social service industry. This evidence was expected given that the pandemic of COVID-19 brought major health problems, with significant impacts on people's social responsibility and quality of life worldwide [2]. Therefore, we can assume that in addition to acting based on motivation by coercive pressure or benchmarking, organisations, such as the health and social service industry, are acting based on the example and the top managers' commitment to the SDGs.

Moreover, the evidence demonstrated that where normative pressures exerted a greater influence, the commitment to the SDGs was more advanced, even being considered as the organisations' strategies. Indeed, studies have shown a relationship between the presence of normative pressures and the organisations' commitment to actions related to sustainable development $[12,14]$. Such a result reinforces, now from the institutional viewpoint, that for sustainability to be a more strategic and integral part of businesses leadership plays a vital role [48].

As far as the SDGs are concerned, on the one hand, a relevant finding concerns the fact that the influence of normative pressures is more associated with specific environmentally oriented SDGs $(6,14$ and 15). This is important since, as noted by The Lancet Public Health [25], the goals associated with environmental sustainability were not being met during the pandemic, which may bring severe implications for the environment in the long term. Thus, the influence of normative pressures associated with the organisations' commitment to these SDGs, as identified in this research, may bring hope that targets related to environmental sustainability can still be achieved. Moreover, this may be deemed a window of opportunity for professional networks such as the Global Compact to address specific targets on the 2030 Agenda.

In this sense, H1a was only partially validated because normative pressures, such as the example given by the leaders and the demands coming from top management, topdown initiatives, and the formal education of the members of the organisation, influenced the organisations' commitment to only a few SDGs.

Concerning coercive pressures, a relevant point is the fact that the education sector was the most impacted. Given that the context of the pandemic deprived millions of children access to education [24], impacting over $90 \%$ of the world's student population and over 1.25 billion learners worldwide [49], the results of this research bring hope to change this reality as organisations influenced by these pressures showed commitment to SDG 4-Quality education. Coercive pressures also impacted the organisations' commitment to SDG 2-Zero hunger and sustainable agriculture and SDG 10-Reducing inequalities. In the first instance, these are considered optimistic results as both of these SDGs were critically compromised by a potential downturn in the global economy during and after the pandemic [25].

Coercive pressures are associated with state regulations and legislation [12,32] and usually bring the most positive impacts for sustainable development [32,33,50]. In this respect, the data showed that the greater the influence of the coercive pressures, the greater the organisations' commitment to most of the SDGs. This evidence reinforces the strength that this type of pressure exerts upon organisations, which may have been influenced both 
by the government action in the face of the problems aggravated by the pandemic [30] and by the social impositions from NGOs, consumers, and activists [34] on companies to commit to sustainable development at this time of the global epidemic.

From the results discussed, H1b was validated, but with reservations. We found that coercive pressures mainly from the government, threats of government legislation in the future, and the actions of activist groups and consumers did influence the organisations' commitment to most SDGs, but not all of them.

As to mimetic pressures, it is worth noting that the manufacturing industry was impacted with higher intensity, which was reflected in advanced involvement with the SDGs. The influence of mimetic pressures was also observed in smaller organisations (up to 19 employees). Such a result may be assigned to the uncertainty that the pandemic scenario brought, especially for small businesses [8], which may have reflected in mimetic behaviour, leading small businesses to imitate practices related to the SDGs performed by the large organisations. Larger companies usually stand out in actions and promotions in which they are recognised as examples of leadership [30].

The data showed that the goals most impacted by mimetic pressures are related to the environment: SDG 7-Affordable and clean energy, SDG 13-Action against global climate change, SDG 14-Life below water, and SDG 15-Life and land. The performance of organisations in these SDGs associated with the environmental agenda was essential during the pandemic. However, the environment has been neglected as it is not directly associated with more urgent issues to solve the problems aggravated by the virus, i.e., the health and economic aspects [2,24].

In the face of the discussions, it is possible to state that hypothesis H1c was also only partially validated. The mimetic pressures were mainly associated with competition in the sector, the growth of interest and the contribution of investors in SDGs, and the uncertainty of the results of actions aimed at the SDGs.

\subsection{Institutional Pressures Intensity Versus SDG Engagement: Clustering Organisations}

Employing analyses of the three institutional pressures separately, we designed Figure 3, highlighting the differences and similarities between the groups found in this study in a continuum related to the intensity of institutional pressure (low vs. high) and commitment to the SDGs. In common, the organisations are mainly from the private sector, operate nationally, are located in the state of São Paulo, Brazil, and are signatories of the Global Compact.
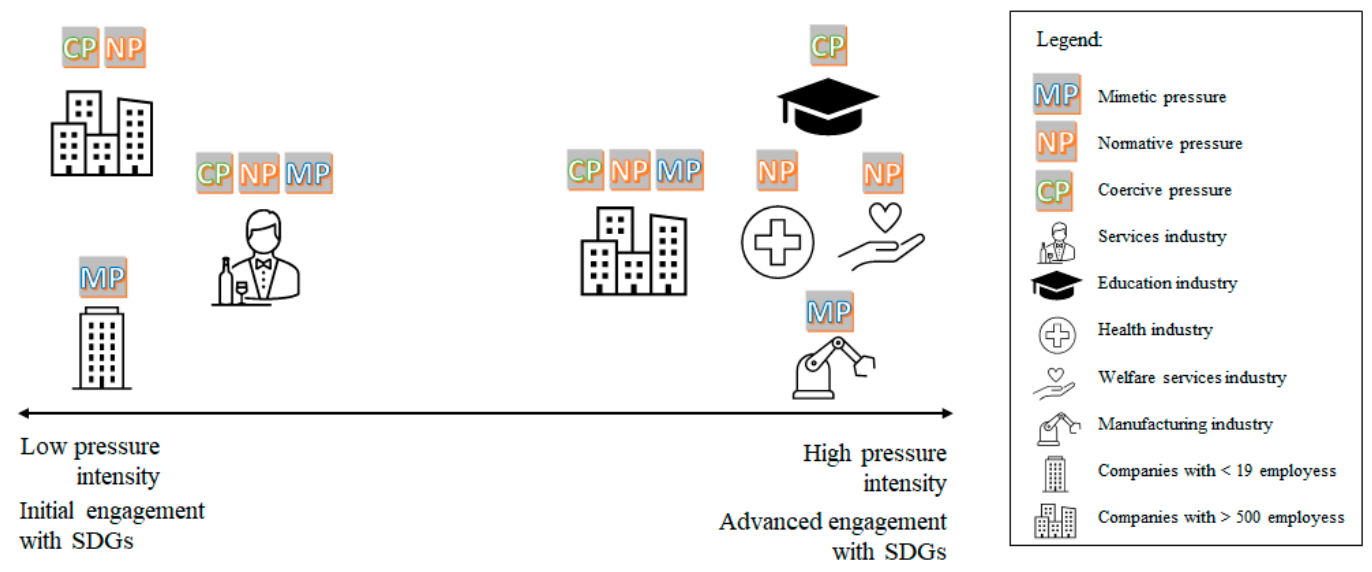

Figure 3. Clusters in a continuum of institutional pressure and engagement with SDGs.

So, in response to the research question "How do institutional pressures influence the commitment of organisations to the Sustainable Development Goals (SDGs) in the context of the COVID-19 pandemic?", we found out that (i) organisations that suffer institutional pressures with higher intensity are engaged at an advanced stage with the SDGs; and (ii) organisations that suffer institutional pressures with lower intensity are engaged at an 
initial stage with the SDGs. Normative pressures influence organisations with a higher intensity, but coercive pressures have a greater impact in terms of varieties of the SDGs addressed, while mimetic pressures also influence the organisations' commitment, but with a lower intensity.

We also demonstrated that organisations from different industries, when strongly engaged with SDGs, and of different sizes, when initially engaged with SDGs, are affected by distinct sources of pressure. As Hoffman [51] suggests, organisations do not simply react to the pressures generated by the organisational field in the same way. Delmas and Toffel [52] add that institutional drivers may have varying sources and exert different effects on sustainability-related initiatives. Accordingly, we recognise that industries differ in maturity and regulatory frameworks regarding sustainable development contributions and sustainability practices. Moreover, we admit that they have different competences in facing the COVID-19 pandemic. So, it is to be expected that the responses to institutional pressures vary according to sectors, as evidenced in this study.

However, the results pointed out that when initially engaged with SDGs, the service industry was affected by all the three sources of pressure: coercive, normative, and mimetic, even if with low intensity. The same is true for large organisations that employ more than 500 people and are in an advanced level of commitment to SGDs, as they were affected by the external pressures with a high intensity. Therefore, further investigations are necessary to identify the factors that influence the differences and similarities of responses in commitment to SGDs regarding the institutional pressures involving both multiple and individual industries.

The evidence in this study points to the fundamental role of regulatory pressures in accomplishing the 2030 Agenda. If, on the one hand, this document provides for the active participation of various social actors, including governments, regulatory and oversight bodies [9], on the other hand, it may trigger a warning about (i) the enduring low involvement of the public sector with the SDGs, and (ii) the dependence on coercion, to the detriment of the proactivity of organisations regarding social and environmental agendas in times of crisis.

Regarding item (i) above, in the case of the country studied, Brazil, and in similar economies [53], initiatives and the involvement of the public sector do exist, but they are still occasional and incipient, whereas concerning item (ii), the dependence on coercion can be even more severe in the case of lack of interest in the 2030 Agenda by the agencies from which such coercion originates. In other words, if there is no interest in coercion, there will be no action or reaction from organisations to address the SDGs.

The present study also provided evidence of the lack of change in the companies' commitment to SDGs in the face of any level of intensity of institutional pressures. Evidence revealed that this was the case for SDG1-No poverty, SDG3 - Good health and well-being, SDG8-Decent work and economic growth, and also SDG12-Responsible consumption and production. In the first instance, given the pandemic's direct impact in triggering health crises [7], increasing unemployment and poverty [5], and the need to establish sustainable production and consumption systems [35], the organisations' commitment to such SDGs could be interpreted from a voluntary point of view, justified by the urgency of these issues and the need to develop quick strategies. Nevertheless, in the second instance, a critical deeper analysis should verify if this is really a result of the organisations' proactivity or if there is inertia or limited influence of the institutional forces over this topic.

Even recognising that answers are being given and solutions are being provided, it is necessary to remember that the pandemic, acting as a lever for unemployment, has caused a dramatic increase in food insecurity, hunger, and food waste [54]. At the same time, a report published by Oxfam Brazil [55] revealed the unequal way the pandemic affected different social classes, exposing more vulnerable layers to extreme poverty and, in the opposite direction, increasing the wealth of others.

To address the impacts of the pandemic, when effective and urgent responses are expected and needed, it is fundamental to set the role, coordination, and synergy of different 
actors, from diverse spheres. Although it is not yet possible to affirm whether cultural changes towards sustainable development will arise from the pandemic [56], this study revealed opportunities and calls if the 2030 Agenda is to be achieved. On the one hand, opportunities are arising from normative and mimetic institutional pressures, from leaders, internal regulations, or benchmarking. However, on the other hand, there is a concrete call for sources of coercive pressures, mainly regulatory and government organisations, to influence and even direct the re-establishment of economic, social, and environmental development and prosperity.

\subsection{Theoretical, Practical, and Social Contributions}

Concerning the theoretical contributions, the application of institutional theory to studies on the sustainability field is corroborated and expanded. In periods of crises, institutional pressures proved to be defining for an organisation's behaviour towards sustainability initiatives. Further research on the same theme and other research questions are necessary, such as: "How do institutional pressures affect the decision making of managers during and post the pandemic?"; "How do institutional pressures in the context of the COVID-19 pandemic provoke isomorphism in private sector organisations?"; and, in the future, "How are the actions initiated in the COVID-19 pandemic institutionalized post-pandemic in organisations?" It is noteworthy that, in isolation, the analysis from the standpoint of institutional theory, or any other, will hardly be able to cover the complexity of the pandemic, but it may contribute with answers to questions such as the one we proposed in this study.

The fact that coercive pressures are predominant in the context of this study still contributes to new insights into the role of the public sector regarding sustainable development. Furthermore, the relevance of coercive actions in a global agenda that, at least in theory, should be adopted and addressed proactively has become evident. Thus, to encourage research in the area, we call attention to further studies on this theme, not only by academics in general but also by editors of scientific journals and funding agencies.

As a practical contribution, we intend to encourage organisations to better direct their efforts to fight the virus without neglecting the 2030 Agenda. This means providing insights for reducing the negative impacts of the pandemic by adapting to the institutional pressures imposed by the current scenario, stimulating the commitment to the SDGs. As the evidence shows, this mission can be contemplated by developing different actions, individually or in networks and alliances, framed for different purposes. There is a clear opportunity for sustainable leadership to inspire and influence actions towards sustainable development, as well as for professional networks and partnerships, mainly on environmental issues.

As a social contribution, this study intends to provoke institutions likely to exert coercive, normative, and mimetic pressures to be aware of their influence's impacts and to better direct it towards the interests of society during and after the pandemic. Furthermore, we also provided awareness regarding institutional pressures to those interested in committing to maintaining the 2030 Agenda in progress to get ahead and to adapt their initiatives.

\section{Conclusions, Limitations and Future Studies}

Affected by institutional pressures or by their own initiatives, organisations are trying to contribute to minimizing the impacts caused by the virus. Nevertheless, despite some optimistic results, we conclude that, given the damage that the pandemic has caused, achieving the purpose outlined by the 2030 Agenda seems to be distant or at least to have become an even more considerable effort if we depend on external pressures.

Due to its exploratory nature, this study did not intend to exhaust the subject. Instead, given a scenario still little studied in the literature due to the contemporaneity of the subject, it is intended to foster debate and stimulate positive impacts amidst the current unprecedented pandemic situation in the world. 
As a limitation, we initially point out the low sample volume. The number of valid responses (72) may not allow generalisation to all organisations in Brazil or other countries. The generalisability of the results may also be limited due to the use of a convenient and non-probabilistic procedure. The $3.25 \%$ response rate is very similar to Lozano and BarreiroGen's [25], who also surveyed corporations in the context of the COVID-19 pandemic. As with that research, we assume that the low return of responses is due precisely to the pandemic scenario that affected the organisations' willingness to address efforts to what was not considered a priority, such as academic research. We add that the character of the quantitative method does not allow deepening insights into how the institutional pressures affect the different actions of organisations. Moreover, considering that the research was developed in a period in which the pandemic had not yet been cured, we admit that the temporal cut used in this research may not have allowed capturing other actions and pressures that have been developed subsequently.

Given these limitations, we suggest future studies to understand how the pandemic directly affects specific aspects and goals related to the SDGs and how this may compromise the achievement of the 2030 Agenda. Similarly, qualitative research that seeks to analyse in depth the role of each institutional pressure for organisations to develop actions on sustainability in the context of the pandemic is recommended. At the same time, in the post-pandemic period, it is interesting to analyse whether the influence of these pressures will be sufficient to institutionalise specific actions and, if so, which elements will permeate the process. Finally, we suggest studies that compare the behaviour of these pressures in different countries to verify how different institutional environments endorse or constrain the influence of pressures on the commitment of organisations to the SDGs.

Author Contributions: Conceptualization, J.A.R.d.S., N.E.B.T. and R.T.d.S.O.; methodology, E.S. and M.S.d.F.-M.; software, E.S.; validation, E.S.; formal analysis, J.A.R.d.S. and N.E.B.T.; investigation, J.A.R.d.S., N.E.B.T., M.S.d.F.-M. and R.T.d.S.O.; resources M.S.d.F.-M.; data curation, E.S.; writingoriginal draft preparation, J.A.R.d.S., N.E.B.T. and R.T.d.S.O.; writing—review and editing, B.G.; visualization, B.G.; supervision, B.G.; project administration, B.G.; funding acquisition, B.G. All authors have read and agreed to the published version of the manuscript.

Funding: This study was carried out with the support of the Higher Education Personnel Improvement Coordination-Brazil (CAPES) - Financing Code 001, the National Council for Scientific and Technological Development (CNPq), and the Federal Institute of Education, Science and Technology of Rondonia.

Acknowledgments: Authors thank to the funding institutions that made this research possible and published.

Conflicts of Interest: The authors declare no conflict of interest.

\section{Appendix A}

Questionnaire-SDGs and COVID-19: actions of organisations in Brazil

- Q1 How is the organisation currently engaging with the SDGs?

There is no concrete engagement with the SDGs yet.

There is a plan to use the SDGs to inform and make changes to the organisation's strategy going forward.

The organisation has already started to analyse the relationships between the SDGs and strategy.

The SDGs are integrated into strategic planning.

- Q2 Considering the context of the pandemic, how high a priority is each of the SDGs given by the organisation you represent?

(1) None (2) Low (3) Medium (4) High (5) Very high

SDG 1-Eradicate poverty

SDG 2-Zero hunger and sustainable agriculture 
SDG 3-Health and well-being

SDG 4-Quality education

SDG 5-Gender equality

SDG 6-Clean water and sanitation

SDG 7-Clean and affordable energy

SDG 8-Decent work and economic growth

SDG 9-Industry, innovation and infrastructure

SDG 10-Reduced inequalities

SDG 11-Sustainable cities and communities

SDG 12-Responsible consumption and production

SDG 13-Action against global climate change

SDG 14-Life below water

SDG 15-Life on land

SDG 16-Peace, justice and strong Institutions

SDG 17-Partnerships and Means of Implementation

- Q3 Considering the context of the pandemic, please indicate the variation in the performance of actions by the organisation you represent:

(1) Reduced significantly during the pandemic (2) Reduced during the pandemic (3) Maintained during the pandemic (4) Increased during the pandemic (5) Increased significantly during the pandemic

Donations of money, materials, and others.

Partnerships with other organisation(s) from different sector(s).

Developing new products and/or offering new services.

Availability of resources (such as logistics networks, communication channels, among others).

Change(s) in the productive process and/or in service provision.

Changes in the productive chain.

Actions geared towards the health care of its employees.

Actions to support small enterprises.

Financing actions or projects.

Expansion of the production capacity and/or the offer of services.

- Q4 How do you think the COVID - 19 pandemic affected the organisation's actions related to the SDGs?

(1) It has affected very negatively.

(2) It has affected negatively.

(3) Continued.

(4) It has had a positive impact.

(5) It has affected very positively.

- Q5 How important do you classify the items below for the organisation to carry out actions related to the SDGs in the context of the pandemic?

(1) Not important at all (2) Not very important (3) Indifferent (4) Important (5) Very important

The example set by top management

Demands made by top management

Top-down initiatives

Top management commitment to the SDGs

Partnerships and alliances with other organisations

Formal education of members of the organisation

The organisation's internal regulations related to sustainable development

The standardisation of SDG performance indicators for business

The emergence of reporting guidelines on the SDGs 
- Q6 How important do you rate the presence of the following items for the organisation to carry out actions related to the SDGs in the context of the pandemic?

(1) Not important at all (2) Not very important (3) Indifferent (4) Important (5) Very important

Government legislation (federal, state or local)

The threat of government legislation in the future

Incentives offered by government

Actions by activist groups

Consumer actions

Actions by third sector organisations (civil society organisations or non-governmental organisations, for example)

Regulations by the sector

Regulations by government

Clearer policy commitments at government level

- Q7 How important do you rate the presence of the following items for the organisation to carry out actions related to the SDGs in the context of the pandemic?

(1) Not important at all (2) Not very important (3) Indifferent (4) Important (5) Very important

Uncertainty of results from actions related to the SDGs

Actions by other organisations considered leaders in the sector

Competition in the sector

Increased interest and contribution from investors in SDGs

Benchmarking in the sector

- Q8 Which economic sector does the organisation you are responsible for belong to?

1st Sector (public organisations, municipalities)

2nd Sector (private organisations)

3rd Sector (NGOs, municipalities, and foundations)

- Q9 What is the size of the organisation?

Up to 19 employees

From 20 to 99 employees

From 100 to 499 employees

More than 500 employees

- Q10 What is the scope of the organisation?

National

Multinational

- Q11 What is the field of activity?

Agriculture, livestock, forestry, fishing, and aquaculture

Extractive industries

Manufacturing industries

Electricity and gas

Water, sewage, waste management activities, and decontamination

Construction

Commerce; repair of motor vehicles and motorbikes

Transportation, storage, and mail

Accommodation and meals

Information and communication

Financial activities, insurance, and related services

Real estate activities

Professional, scientific and technical activities

Administrative activities and complementary services 
Public administration, defence, and social security

Education

Human health and social services

Arts, culture, sports, and recreation

Other service activities

Domestic services

International organisations and other extraterritorial institutions

- Q12 Where are the headquarters of the organisation?

Acre (AC)

Alagoas (AL)

Amapá (AP)

Amazonas (AM)

Bahia (BA)

Ceará (CE)

Distrito Federal (DF)

Espírito Santo (ES)

Goiás (GO)

Maranhão (MA)

Mato Grosso (MT)

Mato Grosso do Sul (MS)

Minas Gerais (MG)

Pará (PA)

Paraíba (PB)

Paraná (PR)

Pernambuco (PE)

Piauí (PI)

Rio de Janeiro (RJ)

Rio Grande do Norte (RN)

Rio Grande do Sul (RS)

Rondônia (RO)

Roraima (RR)

Santa Catarina (SC)

São Paulo (SP)

Sergipe (SE)

Tocantins (TO)

- $\quad$ Q13 What is the organisation's participation in the Global Compact Network Brazil?

Signatory

Participant

Not a member

- Q14 To date, what percentage of the organisation's members have presented cases of COVID-19?
No cases
0-10\%
$11-20 \%$
$21-30 \%$
$31-40 \%$
$41-50 \%$
$51-60 \%$
$61-70 \%$
$71-80 \%$
$81-90 \%$
91-100\% 


\section{References}

1. Lipsitch, M.; Swerdlow, D.L.; Finelli, L. Defining the epidemiology of COVID-19-studies needed. N. Engl. J. Med. 2020, 382, 1194-1196. [CrossRef] [PubMed]

2. Severo, E.A.; De Guimarães, J.C.F.; Dellarmelin, M.L. Impact of the COVID-19 pandemic on environmental awareness, sustainable consumption and social responsibility: Evidence from generations in Brazil and Portugal. J. Clean. Prod. 2021, 286, 124947. [CrossRef] [PubMed]

3. World Health Organization (WHO). Coronavirus Disease 2019 (COVID-19) Situation Report-177. Available online: https: / / www.who.int/docs/default-source/coronaviruse/situation-reports/20200715-covid-19-sitrep (accessed on 15 July 2020).

4. Chen, S.; Yang, J.; Yang, W.; Wang, C.; Bärnighausen, T. COVID-19 control in China during mass population movements at New Year. Lancet 2020, 395, 764-766. [CrossRef]

5. World Trade Organization (WTO). Trade Set to Plunge as COVID-19 Pandemic Upends Global Economy. Available online: https://www.wto.org/english/news_e/pres20_e/pr855_e.htm (accessed on 15 July 2020).

6. World Business Council for Sustainable Development (WBCSD). How Business is Responding to COVID-19. Available online: https:/ / www.wbcsd.org/COVID-19 (accessed on 15 July 2020).

7. Khetrapal, S.; Bhatia, R. Impact of COVID-19 pandemic on health system and Sustainable Development Goal 3. Indian J. Med. Res. 2020, 151, 395. [PubMed]

8. Leal Filho, W.; Brandli, L.L.; Salvia, A.L.; Rayman-Bacchus, L.; Platje, J. COVID-19 and the UN sustainable development goals: Threat to solidarity or an opportunity? Sustainability 2020, 12, 5343. [CrossRef]

9. UN. Transforming Our World: The 2030 Agenda for Sustainable Development. Resolution Adopted by the General Assembly on 25 September 2015. 2015. Available online: http://www.un.org/ga/search/view_doc.asp?symbol=A/RES/70/1andLang=E (accessed on 19 September 2019).

10. Greenwood, R.; Oliver, C.; Lawrence, T.B.; Meyer, R.E. (Eds.) Introduction. In The SAGE Handbook of Organizational Institutionalism, 1st ed.; SAGE: London, UK, 2008; pp. 1-46.

11. Roman, A.V. Institutionalizing sustainability: A structural equation model of sustainable procurement in US public agencies. J. Clean. Prod. 2017, 143, 1048-1059. [CrossRef]

12. Daddi, T.; Testa, F.; Frey, M.; Iraldo, F. Exploring the link between institutional pressures and environmental management systems effectiveness: An empirical study. J. Environ. Manag. 2016, 183, 647-656. [CrossRef]

13. Daddi, T.; Bleischwitz, R.; Todaro, N.M.; Gusmerott, N.M.; De Giacomo, M.R. The influence of institutional pressures on climate mitigation and adaptation strategies. J. Clean. Prod. 2020, 244, 1-9. [CrossRef]

14. Hoejmose, S.U.; Grosvold, J.; Millington, A. The effect of institutional pressure on cooperative and coercive 'green' supply chain practices. J. Purch. Supply Manag. 2014, 20, 215-224. [CrossRef]

15. Rifai, H.S. The sustainable development goals in a bioremediation journal context: What a difference a year makes in a post COVID-19 world! Bioremediation J. 2020, 24, 1-4. [CrossRef]

16. Wijethilake, C.; Munir, R.; Appuhami, R. Strategic responses to institutional pressures for sustainability. Account. Audit. Account. J. 2017, 30, 1677-1710. [CrossRef]

17. Scott, W.R. Intitutions and Organizations: Ideas and Interests, 3rd ed.; SAGE Publications: Thousand Oaks, CA, USA, 2008.

18. Scott, W.R.; Christensen, S. The Institutional Construction of Organizations: International and Longitudinal Studies, 1st ed.; SAGE publications: Thousand Oaks, CA, USA, 1995.

19. Scott, W.R. Institutions and Organization; SAGE publications: Thousand Oaks, CA, USA, 1995.

20. DiMaggio, P.J.; Powell, W.W. The Iron Cage Revisited? Institutional Isomorphism and Collective Rationality in Organizational Fields. Am. Sociol. Rev. 1983, 48, 147-160. [CrossRef]

21. Wang, F.; Sun, J.; Liu, Y.S. Institutional pressure, ultimate ownership, and corporate carbon reduction engagement: Evidence from China. J. Bus. Res. 2019, 104, 14-26. [CrossRef]

22. Gunarathne, N.; Lee, K.H. Institutional pressures and corporate environmental management maturity. Manag. Environ. Qual. Int. J. 2019, 30, 157-175. [CrossRef]

23. Schönherr, N.; Findler, F.; Martinuzzi, A. Exploring the interface of CSR and the Sustainable Development Goals. Transnatl. Corp. 2017, 24, 33-47. [CrossRef]

24. UN. The Sustainable Development Goals Report. 2020. Available online: https://unstats.un.org/sdgs/report/2020/TheSustainable-Development-Goals-Report-2020.pdf (accessed on 2 March 2021).

25. The Lancet Public Health. Will the COVID-19 pandemic threaten the SDGs? Lancet Public Health 2020, 5, e460. [CrossRef]

26. Lozano, R.; Barreiro-Gen, M. Corporate Sustainability and COVID-19: Analysing the impacts of the outbreak. IEEE Eng. Manag. Rev. 2021, 49, 72-80. [CrossRef]

27. Stevens, C.; Kanie, N. The transformative potential of the Sustainable Development Goals (SDGs). Int. Environ. Agreem. Politics Law Econ. 2016, 16, 393-396. [CrossRef]

28. World Business Council for Sustainable Development (WBCSD). The Consequences of COVID-19 for the Decade Ahead-Vision 2050 Issue Brief. Available online: https://docs.wbcsd.org/2020/05/WBCSD_V2050IB_COVID19.pdf (accessed on 15 July 2020).

29. Shubham Charan, P.; Murty, L.S. Organizational adoption of sustainable manufacturing practices in India: Integrating institutional theory and corporate environmental responsibility. Int. J. Sustain. Dev. World Ecol. 2018, 25, 23-34. [CrossRef] 
30. Craighead, C.W.; Ketchen, D.J.; Darby, J.L. Pandemics and Supply Chain Management Research: Toward a Theoretical Toolbox. Decis. Sci. 2020, 51, 838-866. [CrossRef] [PubMed]

31. Cooper, S.; Parkes, C.; Blewitt, J. Can accreditation help a leopard change its spots?: Social accountability and stakeholder in business schools. Account. Audit. Account. J. 2014, 27, 234-258. [CrossRef]

32. Lloret, A. Modeling corporate sustainability strategy. J. Bus. Res. 2016, 69, 418-425. [CrossRef]

33. Escobar, L.F.; Vredenburg, H. Multinational oil companies and the adoption of sustainable development: A resource-based and institutional theory interpretation of adoption heterogeneity. J. Bus. Ethics 2011, 98, 39-65. [CrossRef]

34. Glover, J.L.; Champion, D.; Daniels, K.J.; Dainty, A.J. An Institutional Theory perspective on sustainable practices across the dairy supply chain. Int. J. Prod. Econ. 2014, 152, 102-111. [CrossRef]

35. Hoejmose, S.; Brammer, S.; Millington, A. “Green" supply chain management: The role of trust and top management in B2B and B2C markets. Ind. Mark. Manag. 2012, 41, 609-620. [CrossRef]

36. Cohen, M. Does the COVID-19 outbreak mark the onset of a sustainable consumption transition? Sustain. Sci. Pract. Policy 2020, 16, 1-3. [CrossRef]

37. Bansal, P. Evolving sustainably: A longitudinal study of corporate sustainable development. Strateg. Manag. J. 2005, 26, 197-218. [CrossRef]

38. World Business Council for Sustainable Development (WBCSD). Business and the SDGs: A Survey of WBCSD Members and Global Network Partners. 2018. Available online: http://docs.wbcsd.org/2018/07/WBCSD_Business_and_the_SDGs.pdf (accessed on 10 August 2020).

39. Huan, Y.; Li, H.; Liang, T. A New Method for the Quantitative Assessment of Sustainable Development Goals (SDGs) and a Case Study on Central Asia. Sustainability 2019, 11, 3504. [CrossRef]

40. Huang, Y.C.; Huang, C.H.; Yang, M.L. Drivers of green supply chain initiatives and performance: Evidence from the electrical and electronics industries in Taiwan. Int. J. Phys. Distrib. Logist. Manag. 2017, 47, 796-819. [CrossRef]

41. del Mar Miras-Rodríguez, M.; Machuca, J.A.D.; Escobar-Pérez, B. Drivers that encourage environmental practices in manufacturing plants: A comparison of cultural environments. J. Clean. Prod. 2018, 179, 690-703. [CrossRef]

42. Pedersen, E.R.G.; Neergaard, P.; Pedersen, J.T.; Gwozdz, W. Conformance and Deviance: Company Responses to Institutional Pressures for Corporate Social Responsibility Reporting. Bus. Strategy Environ. 2013, 22, 357-373. [CrossRef]

43. Li, Y.; Ye, F.; Dai, J.; Zhao, X.; Sheu, C. The adoption of green practices by Chinese firms: Assessing the determinants and effects of top management championship. Int. J. Oper. Prod. Manag. 2019, 39, 550-572. [CrossRef]

44. Brazilian Institute of Geography and Statistics-IBGE. Classificação Nacional de Atividades Econômicas-CNAE; IBGE: Rio de Janeiro, Brazil, 2007.

45. Pett, M.A. Nonparametric Statistics for Health care Research: Statistics for Small Samples and Unusual Distributions; SAGE publications: Thousand Oaks, CA, USA, 2015.

46. Gefen, D.; Straub, D. A practical guide to factorial validity using PLS-Graph: Tutorial and annotated example. Commun. Assoc. Inf. Syst. 2005, 16, 5. [CrossRef]

47. Salkind, N.J. Encyclopedia of Measurement and Statistics; SAGE Publications: Thousand Oaks, CA, USA, 2006.

48. Tomšič, N.; Bojnec, Š.; Simčič, B. Corporate sustainability and economic performance in small and medium sized enterprises. J. Clean. Prod. 2015, 108, 603-612. [CrossRef]

49. UNESCO. Education: From Disruption to Recovery. 2021. Available online: https://en.unesco.org/covid19/educationresponse (accessed on 10 March 2021).

50. Campbell, J.L. Why would corporations behave in socially responsible ways? An institutional theory of corporate social responsibility. Acad. Manag. Rev. 2007, 32, 946-967. [CrossRef]

51. Hoffman, A.J. Linking organizational and field-level analyses: The diffusion of corporate environmental practice. Organ. Environ. 2001, 14, 133-156. [CrossRef]

52. Delmas, M.; Toffel, M.W. Stakeholders and environmental management practices: An institutional framework. Bus. Strategy Environ. 2004, 13, 209-222. [CrossRef]

53. Almeida, F. Exploring the impact of COVID-19 on the sustainability of health critical care systems in South America. Int. J. Health Policy Manag. 2021, 10, 462-464. [CrossRef]

54. The Sustainable Development Report 2020—The Sustainable Development Goals and COVID-19. 2020. Available online: https://s3.amazonaws.com/sustainabledevelopment.report/2020/2020_sustainable_development_report.pdf (accessed on 2 March 2021).

55. Oxfam Brazil. O Virus da Desigualdade. Oxfam International. 2021. Available online: https://www.oxfam.org.br/wpcontent/uploads/2021/01/bp-the-inequality-virus-110122_PT_Final_ordenado.pdf?utm_campaign=davos_2021_-_pre_ lancamentoandutm_medium=emailandutm_source=RD+Station (accessed on 2 March 2021).

56. Patel, J.A.; Nielsen FB, H.; Badiani, A.A.; Assi, S.; Unadkat, V.A.; Patel, B.; Wardle, H. Poverty, inequality and COVID-19: The forgotten vulnerable. Public Health 2020, 183, 110. [CrossRef] 